\title{
特集：再考野生動物 の捕獲学
}

第7 回曰本野生動物医学会大会 ワーフショツプ 2001 年 9 月7日 日本大学生物資源科学部

\section{野生動物研究における Animal Welfare 一対象動物と生態系に配慮した調査研究のガイドラインとはー}

\author{
福江佑子'1), 金子弥生 ${ }^{2)}$, 橋本幸彦 ${ }^{3)}$
}

藤井 猛4)，金澤文吾5)，中村俊彦6)，佐伯 緑 ${ }^{7)}$

1) 東京農工大学野生動物保護学研究室 干 183-8509 東京都府中市幸町 3-5-8

2) 国土交通省国土技術政策総合研究所環境研究部緑化生態研究室 $\mathbf{T} 305-0804$ 茨城県つくば市旭町 1 番地

3)(財自然環境研究センター $=110-8676$ 東京都台東区下谷 3-10-10

4) (㑣野生動物保護管理事務所 現 テ 720-0002 広島県福山市御幸町下岩成 939-2

5) 東京農工大学野生動物保護学研究室 現 (社高知県生態系保護協会 ₹ 781-1165 高知県土佐市宇佐町竜 558-2

6) 東京農工大学野生動物保護学研究室 現 埼玉県生態系保護協会 ₹ 330-0802 埼玉県さいたま市宮町 1-103

7)オックスフォード大学動物学部野生動物保護ユニット South Parks Rord, Oxford, OX 13 PS UK.

\section{Animal Welfare in Wildlife Studies}

\section{-What are guidelines for the care of wild mammals in field research-}

Yuko FUKUE ${ }^{1)}$, Yayoi KANEKO ${ }^{2)}$, Yukihiko HASHIMOTO' ${ }^{3)}$,

Takeshi FUJII"), Bungo KANAZAWA ${ }^{1)}$, Toshihiko NAKAMURA ${ }^{1)}$ and Midori SAEKI ${ }^{5}$

1)Wildlife Conservation, Department of Ecoregion Science, Faculty of Agriculture, Tokyo Noko University, 3-5-8 Saiwai-cho Fuchu-shi Tokyo 183-8509

2) Landscape and Ecology Division, Environment Department, National Institute for Land and Infrastructure Management, Ministry of Land, Infrastructure and Transport,

1 Asahi-cho Tsukuba-shi Ibaragi 305-0804

3) Japan Wildlife Research Center, 3-10-10 Shimoya Taito-ku Tokyo 110-8676

4) Wildlife Management Office, 939-2, Shimoiwanari Miyuki-cho Fukuyama-shi Hiroshima 720-0002

5) Wildlife Conservation, Department of Ecoregion Science, Faculty of Agriculture, Tokyo Noko University, 558-2 Ryu Usa-cho Tosa-shi Kouchi 781-1165

6) Wildlife Conservation, Department of Ecoregion Science, Faculty of Agriculture, Tokyo Noko University, 1-103 Miya-cho Saitama-shi Saitama 330-0802

7) Wildlife Conservation Research Unit, Department of Zoology, Oxford University, South Parks Rord, Oxford, OX 13 PS UK.

\footnotetext{
ABSTRACT: We conducted a questionnaire survey on attitudes of carnivore investigators toward animal welfare for wild mammals. Most respondents were aware of the importance of animal welfare, and opined to need the research manuals concerning animal welfare and guidelines for the care of wild mammals in field research. Journal of Mammalogy and Animal Behaviour have established ethical committees for animal care and use. These committees have published and updated guidelines for animal welfare. It is important for these guidelines to include individuals as well as populations, ecosystems and investigators themselves in fieldwork. Although there are no guidelines for wildlife welfare in Japan, many investigators take a great interest in the wildlife welfare, and there is a movement of making guidelines for the care of wildlife. To establish effective guidelines for the care of wildlife, we need to have the ethical committee in the scientific society and more functional laws concerning wildlife.
} 


\section{福江佑子ら}

Key Words : animal welfare, wildlife, questionnaire, guideline

Jpn.J.Zoo Wildl.Med. 7(1) : 23-29, 2002

\section{はじめに}

野生動物 (本稿では野生哺乳類を指す) を直接的に取り扱 う場面は，個人の研究のみならず，行政機関やコンサル夕 ントによる調查, 交通事故や病気等による野生動物の保護 など様々である。日本では，実験動物においては倫理的な 取り扱いのためのガイドラインやそれに沿った作業マニュ アルなどが作成され，研究が行われてきている。しかしな がら，野生動物を対象とした調查研究では，倫理的側面は ほとんど議論されず，調査研究者間の共通した枠組みを提 供するガイドラインもないまま，調査研究上のモラルは個 人に委ねられている状態である。

野生動物を対象に調查研究してきた人の多くが，野外で あるため，または野生動物であるために，対象個体または それをとりまく環境など,さらには調査者自身に負荷（ス卜 レスや環境へのダメージ等)を与えた経験があるであろう。 しかしその経験は生かされぬまま，同じ失敗を繰り返しが ちである。同じ失敗を繰り返さないことが，調査研究を効 率的に進める上でも，犠牲となった動物達に報いるために も重要である。

そこで, 著者らの食肉目調查マニュアル作成準備会では, 野生動物の福祉に配慮したガイドラインおよびそれに沿つ た調查マニュアルの必要性を感じ，1999 および 2000 年度 の日本哺乳類学会大会においてミニシンポジウムや自由集 会を行ってきた。本稿ではこれらの集会をまとめ直し，野 生動物の調査研究者の Animal Welfare*に対する意識調 查の結果と海外の Animal Welfare を考慮した動物の取り 扱いに関するガイドラインの紹介および日本での問題点に ついて論じる。

\footnotetext{
*「Animal Welfare」という言葉は日本では「動物福祉」とい う言葉に訳されることが多いが，適切な訳語であるか不明で あるため,ここではアンケートの記述を除いて(アンケート用 紙には「動物福祉」という訳語を使用)，「Animal Welfare」 とした。
}

食肉類の調査研究者の Animal Welfare に 対する意識調査

野生動物の調查研究者が Animal Welfare に対してどの ような意識を持っているのかを知るために, 1999 年 7 月に 食肉類の研究者を対象にアンケートを実施した。アンケー 卜内容は, 大きく分けて, 調査マニュアルに関する事項, 動 物福祉の意識, 動物の福祉に考慮した動物の取り扱いに関 するガイドラインについてである(表 1)。アンケートを配 布した 73 人のうち 40 人から回答が得られた(回収率 $54.8 \%)$ 。「調查遂行上に失敗の経験や問題はあったか」の 問いに対し， $95.0 \%$ (38 人)が「あり」と答えた(図 1)。「な し」と答えた人は，生きた状態の動物を直接扱う調査をし ていない人であったため，事実上，野外の食肉類を扱う人 は全員「あり」と答えていた。「失敗の内容」は，「捕獲」, 「器具の装着(発信機や夕グなど)」,「麻酔」に関するものが 多く，「放逐」,「個体識別」に関するものもみられた(図 2)。 失敗の内容を細かくみると, 対象動物に影響するもの(表 2-1)とデータに影響するもの(表 2-2)に大きく分けられ た。動物にケガを負わせたり，死亡させた失敗内容として， 「捕獲」時のケガ, 衰弱, 死亡や対象外である幼·若齢個体 の「捕獲」や「麻酔」での死亡や不適正な深度, 「放逐」の 際のケガや手順の過ち,「器具の装着」では発信機の首輪や

表 1 食肉類調查研究者へのアンケート内容

「調査マニュアル」に関して

・調查推敲上に発生した問題点と失敗例

- 失敗に対する対処, 工夫

・動物福祉に配慮した食肉目調查マニュアルの必要性の是非

「動物福祉」に関して

-日本の哺乳類研究における動物福祉の観点の必要性の是非

・動物福祉とはどういうものだと考えるか

「動物の取り扱いに関するガイドライン」に関して

・海外の学会でのガイドラインに対する知識

・ガイドラインに反した研究を行ったことがあるか

・日本における動物福祉に配慮したガイドラインの必要性の是 非 
野生動物におけるAnimal Welfare

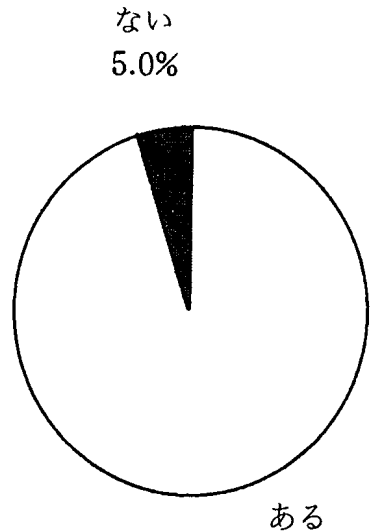

$95.0 \%$

図 1 調査研究で失敗した経験の有無

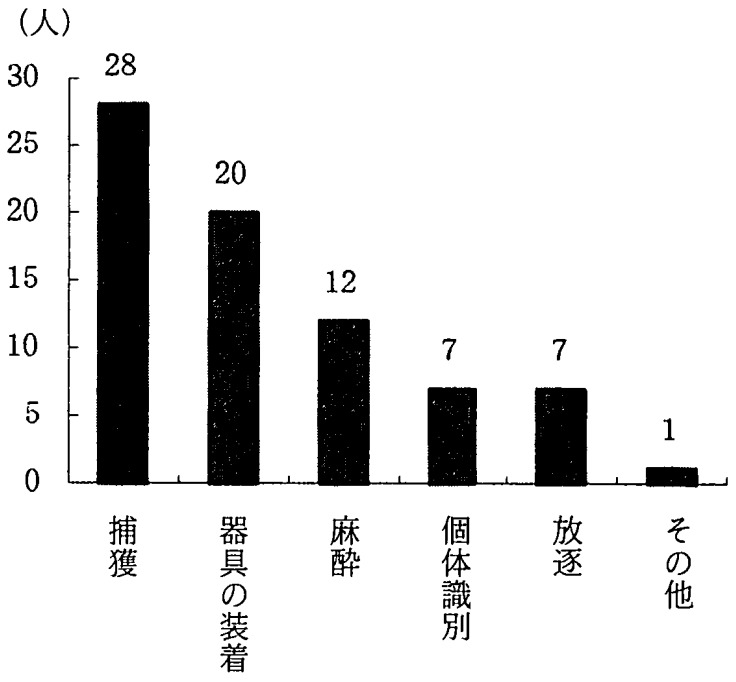

図 2 調査研究で失敗した内容について(回答者 38 人, 複数回 答可)

表 2-1 調査研究に失敗した内容と原因の例 一死亡，ケガなど動物への影響一

\begin{tabular}{|c|c|c|}
\hline & 失敗した内容 & 原因 \\
\hline 捕獲 & $\begin{array}{l}\text { ケガ, 衰弱, 死亡 } \\
\text { 幼・若齢個体の捕獲 }\end{array}$ & $\begin{array}{l}\text { ワナ設置場所や設置時の天候などへの配慮不足 } \\
\text { ワナの設置方法や不備 } \\
\text { ワナの見回りの遅れや漏れ } \\
\text { ワナや捕獲監視用発信の不具合・故障 } \\
\text { 捕獲個体に対する他の動物の攻撃や人為的熼乱 } \\
\text { ワナ設置場所や時期などへの配虑不足 }\end{array}$ \\
\hline 麻酔 & 不適格な麻酤深度, 死亡 & $\begin{array}{l}\text { 投薬量を詥る } \\
\text { 麻酔薬の選択ミス } \\
\text { 衰弱個体への麻酔 }\end{array}$ \\
\hline 放逐 & $\begin{array}{l}\text { 放逐後のケガなど } \\
\text { 䛊った放逐手順 }\end{array}$ & $\begin{array}{l}\text { 十分に麻酔から覚醒させずに放逐 } \\
\text { 取材のため同席していた報道機関による攪乱 }\end{array}$ \\
\hline 器具の装着 & $\begin{array}{l}\text { テレメトリーの首輪の絞まり } \\
\text { テレメトリーの首輪のたすき掛け } \\
\text { 耳標による耳耼午ガ }\end{array}$ & $\begin{array}{l}\text { 成長の予測ミスや体重の季節変化 } \\
\text { 首輪をゆるくしすき } \\
\text { 耳標の大きさの選択ミス } \\
\text { 耳標自体が対象動物に不適 }\end{array}$ \\
\hline
\end{tabular}

表 2-2 調査研究に失敗した内容と原因の例自 ーデータへの影響一

\begin{tabular}{lll}
\hline & \multicolumn{1}{c}{ 失敗した内容 } & \multicolumn{1}{c}{ 原因 } \\
\hline 捕獲 & ワナからの逃亡 & ワナの構造上の問題 \\
& & 予想以上の動物の力 \\
& 蓋のロックなどの確認ミス \\
& ワナの設置場所や方法などの経験不足 \\
\hline 器具の装着 & 首輪の脱落 & ワい \\
\hline 個体識別 & 耳標の脱落 & 体重の季節変化 \\
& 雌雄や年齢の判定ミス & 不適当なマーカーの選択 \\
& & 時期や個体差 \\
& 経験不足 \\
\hline
\end{tabular}




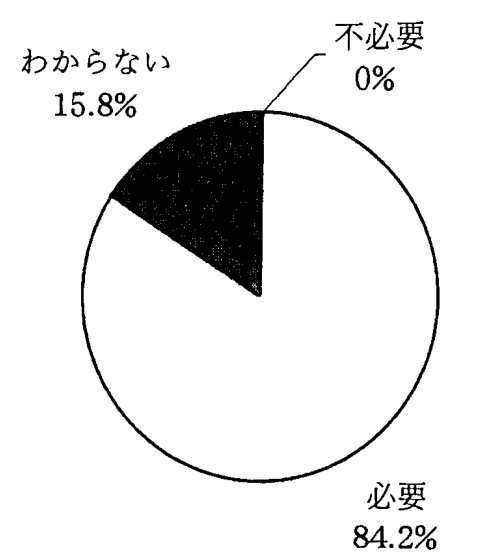

図 3 「食肉目調査マニュアル」の作成の必要性について（回答 者 38 人)

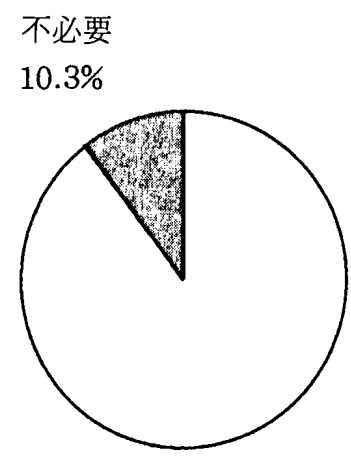

必要

$89.7 \%$

図 4 動物福祉の観点の必要性について（回答者 39 人）

個体識別のための耳標による個体の負傷などが挙げられ た。データに影響する失敗例として，「捕獲」では罠から逃 げられたり，捕獲そのものができないこと，「器具の装着」 では首輪の脱落,「個体識別」では耳標の脱落や雙雄, 年齢 判定の俁りなどが挙げられた。

失敗した原因として「経験不足」,「知識不足」,「人手不 足」が共通に挙げられていた。この結果から，特に失敗や 問題の多くは捕獲時に起こっているということがわかっ た。またその原因の経験不足, 知識不足については, 動物 の取り扱い方法の伝達がロコミによるものが多いためであ ると考えられた。「動物の福祉に考虑した調查マニュアルの 必要性」については，84.2\%(32人)が「必要」であると答 え， $15.8 \%$ (6 人)がわからないと答えていた(図 3 )。「不必 要」と答えた人はなく, 多くの人が動物の福祉に考慮した 調查マニュアルは必要であると考えていることがわかっ

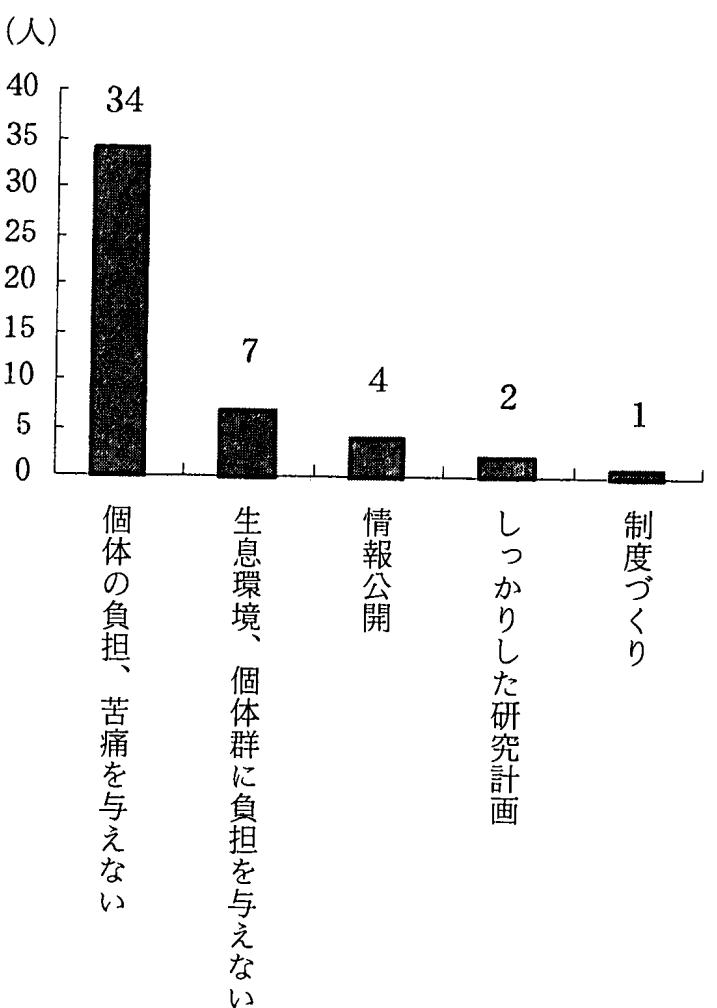

図 5 動物福祉とは何か (回答者 39 人，複数回答可)

た。野生動物の調查や研究に取り組んできた調查研究者の 知識や情報の蓄積として, 調査や捕獲のマニュアルが作ら れ，活用されれば，無䭾な失敗を少しでも回避できるだろ う。それは対象動物やその周辺環境への負担を軽減するこ とになり，なおかつ質の高いデー夕取得にもつながってい $<$ 。

日本の哺乳類研究において動物福祉の観点が「必要」だ と答えたのは $89.7 \%$ (35 人)で，多くの人が「必要」だと考 えていることがわかった(図 4)。動物福祉はどういうもの だと考えるかという問いについては，答えは大きく5つに 分けられた（図 5)。最も多かったのは個体を対象にした「対 象動物に負担・苦痛を与えない」が $87.2 \%$ (34人), 次に, 研究活動による生息環境の破壊を最小限にするという意味 で, 個体群を対象とした「生息環境, 個体群に負担・苦痛 を与えない」が $17.9 \%$ (7 人)であった。その他, 動物福祉 に必要な事項として, 失敗経験を公表することで同じ失敗 を防ぐ「情報公開」 $10.2 \%$ (4 人)，事前に綿密な計画を立て ることにより必要以上のサンプリングや調査個体を減らす といった「研究計画をしっかり立てる」 $5.1 \%$ (2人), 社会 全体の倫理意識向上のための「制度作り」 $2.6 \%$ (1 人)など 
知らない

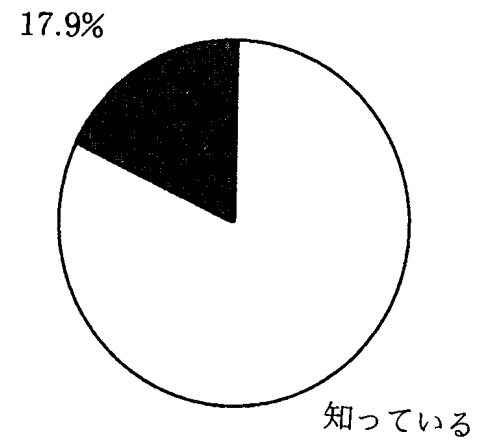

$82.1 \%$

図 6 海外の国際誌の「動物の取り扱いに関するガイドライン」 を知っているか(回答者 39 人)

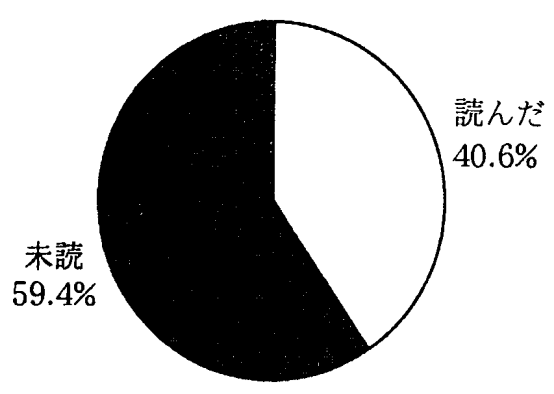

図 7「動物の取り扱いに関するガイドライン」を読んだことが あるか(回答者 32 人)

の回答があった。

海外の科学雑誌における動物の取り扱いに関するガイド ラインの存在については, $82.1 \%$ (32人)が「知っている」と 答えた(図 6)。しかしガイドラインを読んだことがあると 答えた人は,知っている人のうちの $40.6 \%$ (13人)に過ぎず (図 7)，またそのうち $61.5 \%$ (8) 人)読んだガイドライン に沿わない調査研究を行ったことがあると答えていた。ま た，日本における動物福祉を考虑した野生動物の取り扱い に関するガイドラインの必要性については，回答者のうち $91.7 \%$ (33人)が「必要」, $8.3 \%$ (3 人)が「わからない」と 答え，「不必要」と答えた人はいなかった(図 8)。これらの 結果から，ほとんどの研究者は動物の取扱いに関する海外 のガイドラインの存在を知っており，その必要性を認めて いるが，その内容まで理解し実践している人は少ないこと がわかった。また，必要性を認めるものの「時期を検討す

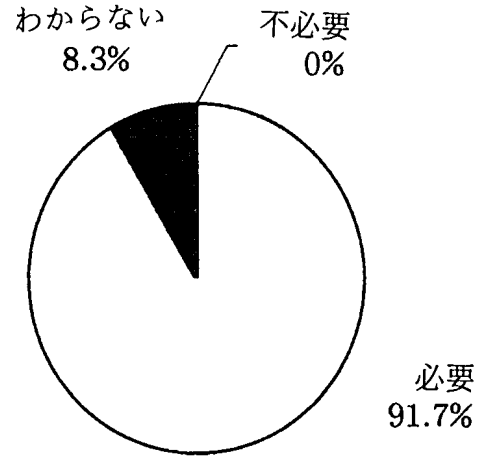

図8日本における動物福祉を考虑した「動物の取り扱いに関 するガイドライン」は必要か (回答者 36 人)

べき」という意見や「研究ができなくなると困る」といつ た多少懐疑的な意見も挙げられた。

\section{海外における Animal Welfare を考慮した 動物の取り扱いに関するガイドライン}

国際誌で動物の取り扱いに関するガイドラインの有無に ついて調べたところ, 調査した 25 誌のうち, 独自のガイド ラインのある雑誌は 2 誌 (Journal of Mammalogy, Ani. mal Behaviour)で, 他誌や他団体のガイドラインを採用し ている雑誌が 6 誌, 調查地の法律に基づくとする雑誌が 5 誌,ガイドラインを設けていなかった雑誌が 12 誌となって いた。海外においても Animal Welfare を考慮した野生動 物の取り扱いのガイドラインの制定は，まだ進んでいる状 態ではない。

独自にガイドラインをもつ Journal of Mammalogy [1] および Animal Behaviour [2] のガイドラインについて簡 単に紹介する。詳細は各雑誌に掲載されているガイドライ ンを読んでいただきたい。

Journal of Mammalogy(The American Society of Mammalogists)では, Animal Care and Use Committee (動物の取り扱いと使用の委員会)により，ガイドラインが 設けられている。1987 年に現在のガイドラインの前身にな る「哺乳類学における容認できる野外調査法」が作られた。 これは「Animal Welfare」と野外調査者のためのガイドラ インと明記されている。以後, トランスポンダなどの技術 の進歩と使用する動物への人道的取り扱いの高まり，また 動物の取り扱いから被る野外調査者のリスクの認識などを 受けて, 現在のガイドラインとなっている。ガイドライン 
は毎年 1 回学会誌に掲載され，必要に応じて更新されてい る。目次は以下の通りである。

\section{アメリカ哺乳類学会員により承認された哺乳類の捕獲,} ハンドリングおよび取り扱いのガイドライン

1. 序論

背景と歴史

哺乳類学におけるフィールドワーク

哺乳類研究者が標本を集める理由

適切なサンプルとは何か

危機にさらされた生息地でのサンプリング

2. 法律と規定の遵守

3. 標本収集のための方法

生け捕り

捕殺と射殺

4. 生きている哺乳類からの組織収集の方法

5. 依存している子どもに対する責任

6. 社会的相互作用

7. 安楽死の方法

8. マーキングと追跡方法

9. 飼育動物の所有と移送

10. 飼育下における野生個体の維持

11. 捕獲された哺乳類の放逐

12. 健康管理

13. 調査地における一般の人々との関係

Animal Behaviour 誌は, アメリカ (The Animal Behavior Society), イギリス(The Association for Study of Animal Behaviour)，それぞれの学会で倫理委員会をもっ ており,それらの委員会が共同で行動研究に従事する人, 動 物を使用して教育活動に従事する人が利用するためのガイ ドラインを作成した。このガイドラインは, 倫理的な枠組 みを提供するものと明記されている。目次を以下に示す。

行動研究と教育における動物の取り扱いに

関するガイドライン

1. 法律

2. 種の選択と動物を使用しない代替法

3. 個体数

4. 手順
(a) 野外調查
(b) 攻撃, 捕食, 種内殺し
(c)動機づけの手順としての嫌悪的刺激と剝奪
(d) 社会的剝奪, 隔離および過密
(e)有害な状態

5. 絶隇危惧種
6. 動物の調達

7. ハウジングと動物の取り扱い

8. 最終的な動物の処置(処分)

9.さらに情報を得るために

これら 2 つのガイドラインとも,データのサンプリング, 捕獲, 安楽死, 飼育等に関し, 人道的(素早く, 痛みがなく) に，ダメージやインパクトを最小限にとどめるように行う べきだとしている。その際, 研究または教育の対象となる 個体に配慮するだけでなく, 個体間関係, 個体群, 生態系, 調査者の健康にまで考慮すべきであると述べている。野生 動物は個体が独立して生存しているのではなく, 親と子, オ スとメスなど同種間の個体間関係や捕食－被食といった異 種間関係，水・土壤・ $\mathrm{pH}$ 等の非生物的要素との関係など異 なるレベルが相互作用する生態系の中で存在するものであ る。この考えに立脚すると, 野生動物を対象としたガイド ラインは,アンケートで多くの研究者が対象としていた「個 体」だけではなく，「個体群」，「生態系」にまで対象を抬げ， 新たな概念として「野生動物の福祉」を捉えるべきではな いかと考える。

\section{Animal Welfare を考慮したガイドライン 策定に向けての問題点と課題}

2001 年 10 月に開催された日本哺乳類学会において,「標 本の取り扱いに関するガイドライン」が策定された。また 著者らが Animal Welfare に配慮した動物の取り扱いの全 体的なガイドラインの策定を呼びかけているように，日本 においても野生動物の取り扱いに関するガイドライン策定 に向けての方向性が徐々に形成されつつある。

学会におけるガイドラインの策定の流れを日本と海外で 比較してみる。海外の場合, 動物の倫理的使用に関する法 律として The Animal Welfare act(アメリカ), The Animal (Scientific Procedure)Act(イギリス), The Animal Research Act (オーストラリア)などがあり, また行政 機関が提供するガイドラインもある。これに応じて学会に は倫理委員会または倫理に関する審議会が存在し, そこで 学会のガイドラインが策定される。もしガイドラインの精 神を犯すような論文がその学会に提出された場合には, 審 議された上で却下される。つまり，倫理委員会があること でガイドラインに効力が備わる。日本では学会での倫理委 員会がないため, ガイドラインが策定されても規制力, 効 
力を伴うのは難しいと思われる。また日本では野生動物の 取り扱いに関する法律は皆無と言っても過言ではない。日 本での Animal Welfareに考慮したガイドラインの作成 は，土台のないまま，建物を立てているような状態なので ある。しかし今の日本では, 土台となる法律を待っていて は, 何十年かかるかわからない。現時点で取り組むべきこ とは,ガイドラインという共通認識を作り上げていくこと である。そのためには個人での Animal Welfareへの認識 を高め，ガイドライン策定に向けての組織作りが急務であ ろう。

\section{要約}

近年, 日本においても「Animal Welfare(動物福祉)」の 考えは浸透し, 特に実験動物では, 倫理的な取り扱いのた めのガイドラインや作業マニュアルなどが作成されてきて いる。しかし，日本では野生動物に対する「Animal Welfare」の意識は低く, 共通認識すら出来上がっていない。す なわち,動物の取り扱いは個人のモラルに委ねられている。 野生動物の場合, 実験動物における「3 Rs (Replacement, Reduction, Refinement)」全てを実施することは難しく, 個体そのものだけではなく，個体の属する個体群や生態系 まで配慮して調査研究を行うことが求められる。
食肉目調查マニュアル作成準備会では，上記のことを鑑 み,「野生動物の福祉」を考慮した食肉目調査マニュアルの 作成とともに「野生動物の取り扱いに関するガイドライン」 の策定を呼びかけるための準備として, 食肉目の研究者を 対象にアンケート調査を行った。その結果, 回答者の約 $90 \%$ が哺乳類研究において「動物福祉」の観点と「野生動 物の取り扱いに関するガイドライン」が必要だと回答した。 また調查遂行上, 発生した問題点や失敗例に関する設問に 対し, $95 \%$ が失敗の経験があると答え, その内容は捕獲, 器 具の装着, 麻酔に関するものであった。本稿では, 食肉目 研究者から得られたアンケート結果と, 海外の「動物の取 り扱いに関するガイドライン」を紹介し，日本における野 生動物調査研究における問題点と課題を論じる。 キーワード： animal welfare, 野生動物, アンケート, ガ イドライン

\section{引用文献}

1. Animal Care and Use Committee. 1998. Guidelines for the capture, handling, and care of mammals as approved by the American Society of Mammalogists. J. Mammal. 79: 1416-1431.

2. Association for the Study of Animal Behaviour. 1998. Guidelines for the treatment of animals in behavioural research and teaching. Anim. Behav. 55:251-257. 